\title{
Current Perspectives on Monetary POLICY
}

\author{
Manuel H. Johnson
}

Rather than discuss the specifics of the Federal Reserve's current concerns and goals for policy, I wish to discuss the more fundamental long-term goals of monetary policy and how we can proceed to reach these goals-particularly under current domestic and international monetary arrangements. Clarifying the goals of policy is especially important in our current monetary environment in which essentially every currency in the world is directly, or indirectly, on a pure fiat standard. ${ }^{1}$ In such circumstances, the credibility of the world's monetary authorities is of utmost importance.

\section{Appropriate Goals of Monetary Policy}

Despite all of our problems, we have learned a great deal about the appropriate goals of monetary policy in recent years. We know, for example, that under fiat arrangements, price stability is an achievable goal and should be a principal objective of monetary policy. A policy that fosters steadiness and predictability in the general price level is essential for genuine noninflationary economic growth.

We have also learned that sharp unanticipated changes in monetary policy can be disruptive to the economy. Accordingly, the pursuit of price stability should also seek to minimize such short-term disruptions to economic activity.

Among monetary experts, there probably is little disagreement on these policy goals. However, there is currently a good deal of disagreement on how to best achieve these objectives.

Cato Journal, Vol. 8, No. 2(Fall 1988). Copyright (C Cato Institute. All rights reserved. The author is Vice Chairman of the Board of Governors of the Federal Reserve System. This paper is based on a luncheon address Governor Johnson gave at the Cato Institute's Sixth Annual Monetary Conference, Washington, D.C., February 25, 1988. 'See, for example, Friedman and Schwartz (1986, p. 38). 


\section{Cato Journal}

\section{The Conduct of Monetary Policy}

\section{Deterioration in the Performance of Monetary Aggregates}

Until a few years ago, there was a growing consensus among monetary economists that the best way to conduct policy was to target monetary aggregates as an intermediate objective. It appeared that the quantity of money was a superior target for the Fed to use in order to achieve price stability and to promote stable economic activity.

Unfortunately, in recent years it has become evident that the relationship between the monetary aggregates and income has become less predictable. Various measures of the velocity of money, for example, have experienced large deviations from trend during the 1980s. Indeed, over this period the velocity decline for most monetary aggregates has been unprecedented in the postwar era. And, as yet, this decline is not fully understood. Consequently, future movements in velocity remain uncertain.

There are several factors that have contributed to this deterioration in performance of the monetary aggregates. While it is probably premature to draw any definite conclusions, it appears that the interaction of deregulation, disinflation, and sizable movements in interest rates have worked to alter the behavior of money supply measures. Due to these factors, money growth is much more sensitive to changes in interest rates and opportunity costs than was previously the case. Since this increased sensitivity works to lessen the predictability of the relationship between money and GNP, these aggregates become less reliable as policy targets.

Admittedly, it is probably too early to conclude that the monetary aggregates will not be useful in the future as policy indicators or targets. But even if stable, predictable velocity reemerges, it will take an extended period before enough confidence and credibility can be mustered so that money supply measures can be used as the sole intermediate target of policy.

\section{Alternative Indicators for Implementing Monetary Policy}

Given this (at least temporary) deterioration in the performance of the monetary aggregates, what alternative indicators are available for implementing policy? Policymakers, after all, necessarily will use some guides in executing policy. What properties or characteristics should such indicators possess?

First, useful indicators should be accurately measurable and readily available. Second, they should respond to changes in Federal Reserve policy actions. And third, they should be reliably related to the ultimate goals of monetary policy. A corollary to these guidelines 
is that monetary policy can only reliably influence nominal but not real variables. It is well known, for example, that attempts to target variables such as unemployment, or real growth, can lead to procyclical, destabilizing movements in general prices.

Given these guidelines, there has been some interest recently in the use of nominal prices of certain financial instruments traded in auction markets. Such interest has not been to use these prices as policy targets but rather as indicators or informational supplements to policy. Preliminary research suggests that these variables may satisfy the above-cited criteria for policy indicators. More specifically, information contained in the term structure of interest rates (yield curve), the foreign exchange market, and certain broad indices of commodity prices has proven useful in the formulation of monetary policy.

Other things equal, all of these indicators should provide signals as to when monetary policy becomes expansionary (easy) or restrictive (tight). This is particularly the case when these indicators are examined together or in conjunction with one another. For example, should one observe the simultaneous occurrence of steepening yield curve, increasing commodity prices, and a depreciating dollar, then it may be inferred that monetary policy most likely has been expansionary.

However, this approach certainly is not foolproof and when such indicators are followed in isolation they can sometimes prove to be misleading. These indicators can be volatile and are sometimes determined or influenced by factors other than monetary policy. Also, they are not always independent from each other and can be affected by expectations of policy change.

Despite these caveats, preliminary evidence is promising enough to suggest that these indicators may prove useful in the formulation of policy. In particular, each of these indicators can provide useful information. When used cautiously and in conjunction with one another so as to piece together a consistent intepretation of overall policy, they can often provide valuable insights into the policymaking process. And being nominal variables, if they are used in a strategy to foster price stability, they will work to prevent any major monetary policy mistakes. If nothing else, they provide useful information that should not be ignored.

The use of market-determined prices as policy indicators (or informational supplements) is an appealing strategy for several reasons. First, the data measuring these variables are readily available, literally by the minute. These market prices provide observable, timely, and more accurate information than is provided by other 


\section{Cato Journal}

sources. There are no problems with revisions, seasonal adjustment procedures, or shift adjustment corrections that plague quantity or volume data. Moreover, the strategy does not rely on unobservable variables such as real interest rates that depend on accurate measurements of future price expectations.

Second, the strategy is premised on the notion that market prices encompass the knowledge and expectations of a large number of buyers and sellers. And while it is true that individual market participants may be irrational, this is not likely to be the case for the market as a whole. Therefore, financial auction market prices reflect the consensus about the current and expected future values of financial instruments. As such, these prices serve as communicators of changing knowledge of market conditions.

Third, since there is evidence that the broader price measures such as the CPI or GNP deflator are slow to reflect new information, changes in monetary policy should be reflected in financial auction market prices well before they affect the broader price measures. Thus, there is reason to believe these prices may give advance warning of impending change for important concerns such as inflation.

It is worth noting that monitoring financial markets in conjunction with one another to piece together a consistent interpretation is not novel. During the period when England had gone off the gold standard in the early 19 th century, for example, classical monetary writers monitored such indicators to assess central bank policy. There is a passage in the famous Bullion Report published in 1810 in which this is clearly documented. Because financial innovations had occurred and accurate and timely monetary statistics were not available at the time, these monetary analysts argued that the central bank should use financial market prices as guides to policy.

In the following brief discussion I cannot possibly provide a detailed analysis of all the research and evidence pertaining to the yield curve, the foreign exchange rate, or commodity prices. Nor can I provide any simple, foolproof prescription on how these indicators should be interpreted. Suffice it to say that there are some difficulties associated with each of the indicators as separate forecasting tools. But when examined together, they often yield valuable insights in evaluating the stance of monetary policy and particularly in assessing movements in expectations of inflation.

With this in mind, I will provide a rough sketch of how each of these market prices may provide useful insights into policy. Each 


\section{YES! I want to subscribe to the CATO JOURNAL.}

$\square 1$ year $\square 2$ years $\square 3$ years $(\$ 21.00) \quad(\$ 42.00)$

$\square$ New subscription $(\$ 63.00)$ $\square$ Renewal

My name

Address

City

State Zip

(For foreign subscriptions, please add $\$ 5.00$ per year regular delivery and $\$ 10.00$ per year airmail delivery.)

My comments on the JOURNAL:

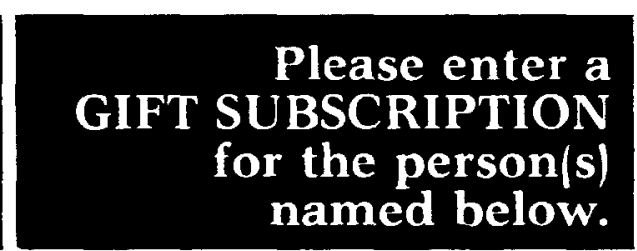

$\square 1$ year (\$21.00) $\square 2$ years

$\square$ New subscription

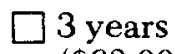
3 years

Gift to

Address

City

State

Zip

Renewal

$\square$ $(\$ 21.00)$

2 years $(\$ 42.00)$

3 years $\square$ New subscription $(\$ 63.00)$ $\square$ Renewal

Gift to

Address

City

State Zip

A special announcement card will be sent to the recipients of your gift and library subscriptions.

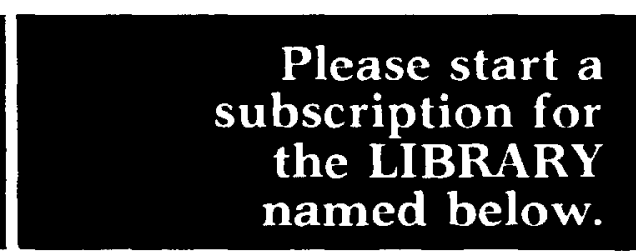

$\square$ 1 year $\square$ 2 years $\quad \square$ 3 years
$(\$ 35.00)$
$\square$ New subscription $\quad \square$ Renewal

Library

Address

City

State Zip

Total: $\$ \square \square$ Check enclosed. Please bill my: $\square$ Visa $\square$ Mastercard Account \#

Exp. date

Signature

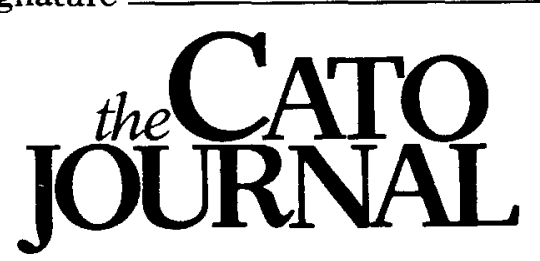




\section{BUSINESS REPLY MAIL}

FIRST CLASS PERMIT NO. 13690 WASHINGTON, D.C. 20024

Postage will be paid by addressee

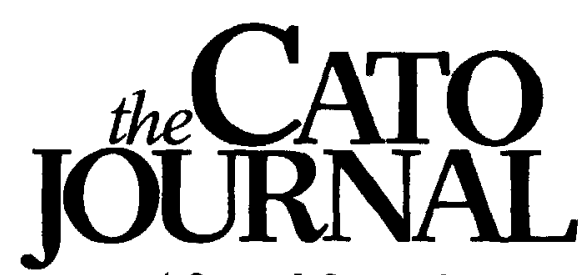

224 Second Street SE

Washington, DC 20003 
indicator makes a contribution to this approach, but these indicators are not intended to be used as explicit targets for policy.

\section{The Yield Curve}

With respect to money and bond markets, empirical evidence suggests that expansionary monetary policy is often reflected in a more positively sloped yield curve whereas a yield curve that becomes inverted (negatively sloped) often reflects a restrictive policy stance. ${ }^{2}$ Inverted yield curves, for example, have preceded most recessions in the postwar era. Indeed, the results of one recent study indicated that the spread between the Fed funds rate and the long bond rate outperformed three other variables as an indicator of the impact of the monetary policy on future real economic activity. ${ }^{3}$

Most analysts do believe that there is useful information reflected in the yield curve. And there are theoretical reasons and evidence to suggest that this spread reflects expectations of future yields as determined in part by expectations of future inflation. These observations imply, of course, that it is not the level of interest rates but the change in the spread that may serve as a useful indicator of the posture of monetary policy.

But one cannot perfectly predict the effects that a change in policy will have on the yield curve; hence this indicator should not serve as a target of policy. The yield curve is affected by a number of other factors such as changes in Treasury funding policy, altered risk premiums, and tax policy, as well as changes in liquidity preference.

Consequently, while the yield curve may provide useful information about monetary policy, it must be interpreted with caution and reservation. The yield curve is certainly not an infallible indicator. ${ }^{4}$ However, when it is analyzed in conjunction with other market prices, the yield curve can be interpreted with more confidence and can make an important contribution to policymaking.

${ }^{2}$ The yield curve referred to in this paper is the spread between the Federal funds rate and the 30-year Treasury bond rate. It is important for the arguments made herein that the funds rate be used as the appropriate short-term rate since it is this rate that Fed monetary policy most directly infuences.

${ }^{3}$ See Laurent (1988).

${ }^{4}$ While useful in assessing the thrust of monetary policy, the spread between the Fed funds rate and the long-term bond rate does not necessarily tell us anything about changes in inflationary expectations. 


\section{Cato Journal}

\section{Commodity Prices}

There is also some empirical evidence to suggest that broad indices of commodity prices respond to changes in monetary policy and tend to lead changes in broader measures of inflation. Governor Angell's research project, indicating that commodity prices lead turning points in the CPI, is interesting in this regard (see Angell 1987). Of course, there remain questions as to exactly which commodities and weights should be employed in such a broad index. Research is currently under way at the Federal Reserve to investigate these questions and examine these relationships.

It is true that the reliability as well as the quantitative importance of these empirical relationships have not been firmly established. And little evidence exists that indicates the Fed can accurately control such indices. Moreover, commodity prices are volatile and are influenced by a number of factors not related to monetary policy. Accordingly, commodity prices are more valuable as an indicator for monetary policy than as an explicit policy target.

\section{The Foreign Exchange Value of the Dollar}

It has long been recognized that the foreign exchange value of the dollar can also provide useful information for monetary policymakers. The exchange rate often indicates the stance of U.S. monetary policy relative to that in other countries. As such, the exchange rate offers a gauge of relative monetary expansion or contraction.

For example, if the dollar is depreciating while the yield curve is steepening and commodity prices are rising, policy is likely expansionary and perhaps overly so. On the other hand, if the dollar is depreciating while commodity prices and the yield curve are stable, the dollar may reflect restrictive foreign monetary policy or other external factors. ${ }^{5}$ Moreover, if the dollar was declining and the yield curve was steepening but commodity prices remained stable, this could reflect an outflow of foreign funds from the U.S. bond market for reasons other than inflationary expectations.

Monitoring exchange rate movements to supplement other indicators, of course, is not foolproof. The exchange markets are volatile and intervention can (at least temporarily) distort signals from this market. Moreover a great deal of information about foreign economic performance and policy is required to properly assess.this market.

${ }^{5}$ In assessing movements in commodity prices and the dollar, it should be mentioned that commodity prices denominated in foreign currencies or special-drawing rights (SDRs) should also be monitored in order to assess whether commodity price movements reflect world inflation or exchange-rate-related domestic price movement. 
It should also be pointed out that exercises in international coordination of monetary policy-which necessarily implies a move to more stable exchange rates-tend to lessen the information content of foreign exchange rates. While stable exchange rates are desirable, stability removes information from this market. After all, it is (theoretically) possible to have either rapid inflation or rapid deflation with stable exchange rates.

Accordingly, information provided by commodity prices and yield curves may assume more importance in analyzing inflationary expectations should coordination be used to stabilize exchange rates.

\section{Additional Considerations}

It could be argued that since the Federal Reserve will be watching the markets and market participants will be watching the Fed, there is a simultaneity problem with the approach I have suggested. Accordingly, there is a risk that market price volatility will increase and that market prices and the Fed funds rate will spiral up and down together.

Concerns that this strategy will bring about increased volatility or instability are ill-founded for several reasons. First, some economic or fundamental event has to initiate market price movement; such events must either cause the Fed to act or the markets to anticipate Fed action. Anticipations do not change for no reason.

An example serves to illustrate that this strategy will not foster unstable or volatile market conditions. Indeed, such a strategy may work to stabilize such prices. Suppose, for example, that commodity prices and long-term interest rates started to increase while the dollar began to depreciate. It might be anticipated that the Fed would tighten policy. This anticipation may or may not lead to higher longterm rates. But anticipations of Fed tightening would not lead to higher commodity prices or a lower dollar. If anything, such anticipations would work to dampen both increases in commodity prices and further dollar depreciation. And such anticipations certainly would not lead to an upward spiral in long-term rates. In fact, long-term rates would continue to rise until the Fed had tightened policy enough to reduce or reverse the initial economic pressures that led to higher commodity prices and a weakened dollar in the first place. Just because the Fed moves the Fed funds rate in one direction does not mean that long-term rates will always move in the same direction. There are many cases where a funds rate movement in one direction has elicited movements in long-term rates in the opposite direction. 


\section{Cato Journal}

In short, such a strategy may work to stabilize rather than to destabilize these markets. Moreover, if the Federal Reserve has garnered a good deal of credibility, there should not be important movements in commodity prices, the dollar, or long-term rates due to changes in price expectations.

The timing of any potential Fed responses to these indicators is also a relevant concern. Clearly, the Fed will wait for a certain amount of time for confirming evidence regarding market price movements before responding to signals from these indicators even when all three are pointing in the same direction. The volatility of these prices, the fact that expectations can affect these markets, and the fact that these markets are not independent, all suggest the appropriateness of allowing for a reasonable period of time to observe trends. After all, the lapse of a certain amount of time may allow overreactions or false expectations of policy action to unwind. On the other hand, the Fed does not want to delay too long or it will forgo the advantages of using such price data. Certainly the magnitudes of the price movements will also alter the response time.

\section{Conclusion}

In spite of several caveats and in the absence of reliable alternative indicators, financial auction markets can provide useful information to the process of monetary policy formulation. I believe the strategy outlined here provides a framework for focusing monetary policy on the conditions for price stability. And price stability is a goal that should direct our attention to these markets.

\section{References}

Angell, Wayne D. "A Commodity Price Guide to Monetary Aggregate Targeting." Paper presented for the Lehrman Institute, 10 December 1987.

Friedman, Milton, and Schwartz, Anna J. "Has Government Any Role in Money?" Journal of Monetary Economics 17 (January 1986): 37-62.

Laurent, Robert D. "An Interest Rate Based Indicator of Monetary Policy." Federal Reserve Bank of Chicago Economic Perspectives 12 (January/ February 1988). 